\title{
Palestine-Israel and the Neoliberal Ideal
}

\author{
Luke Mathew Peterson
}

\begin{abstract}
The following study envisions the modern history of the Palestinian-Israeli conflict through the application of previously underutilized theoretical frames. Beginning with the unprecedented political and social upheaval wrought upon the Middle East after the end of World War I, the article unfolds in three distinct sections. The first section provides an historical introduction to the global, transnational forces that guided the developing infrastructure of political conflict within the region. The second section articulates the ideological parameters of the international political and economic forces ("neoliberalism") that connect the past and present of political conflict in the region as well as the local (state and non-state) and non-local actors involved in its contemporary manifestation.
\end{abstract}

The third and final section reconceptualizes the Palestinian-Israeli conflict not exclusively as a territorial dispute or as a nebulous clash of cultures, but rather as a deliberate, operational casualty

$\overline{\text { Luke Mathew Peterson is currently an instructor of Arabic in the International Relations De- }}$ partment at Duquesne University in Pittsburgh. For the academic year 2014-15, he served as a visiting assistant professor in contemporary international issues in the University of Pittsburgh's Global Studies Center. He has a BA (History, University of Texas, 1999), Master of Liberal Arts (St. Edward's University, 2004), an MA (Middle Eastern Studies, University of Texas, 2007), and a PhD (The University of Cambridge [King's College] in the Faculty of Asian and Middle Eastern Studies, 2012). His PhD investigated the language, media, and knowledge surrounding the Palestinian-Israeli conflict. He has published in the British Journal of Middle Eastern Studies, authored chapters in three anthologies, and written a monograph entitled Palestine in the American Mind: The Discourse on Palestine in the Contemporary United States. His latest book is Palestine-Israel in the Print News Media: Contending Discourses (Routledge: 2015). This research was made possible, in part, by a IIIT small grant. 
enduring in the service of an aggressive, transnational, and indeed historical force whose trajectory spans the length of the twentieth and early twenty-first centuries: neoliberalism. In each sphere in which the neoliberal ideal has been applied - one, an historical fait accompli, another, a contemporary situation en cours - an important, connective element persists: the distinctly non-local origin of both the historical forces and the contemporary economic manifestations under examination.

\section{Introduction: Theorizing the Palestinian-Israeli Conflict}

Contemporary political crises throughout the Middle East are commonly examined via ideologies of conflictual nationalism. As constructed in both positivist and negativist discourses ${ }^{1}$ at the local and regional levels, political conflicts propelled by socially and politically motivated nationalism grip the Middle East, inspiring regional violence, predicating political de-development, ${ }^{2}$ and threatening - or actually enacting - economic collapse throughout the affected region. In Palestine-Israel, the historical trajectory of nationalpolitical conflict has been the subject of a great deal of investigation, revision, repudiation, and disputation, given the myriad of actors and institutions involved at the inception of the area's national-political crisis. Debates as to the origin and nature of this specific conflict likewise retain their vitality in contemporary discussion, given the unyielding nature of regional conflict: a repressive military occupation and political negation that shows no signs of abating. And yet, despite the plurality of voices on the origins of this national-political conflict, intellectual clarity remains elusive.

This study connects the historical trajectory of post-World War I crisis in Palestine with the daily unfolding of that crisis in the Occupied Territories today. In order to establish these connections, traditional (nationalpolitical) academic approaches will be eschewed in favor of an under-utilized conceptual pathway. ${ }^{3}$ The approach embraced here, which foregrounds the force of "neoliberalism," describes movements toward the ubiquitous privatization that, in turn, fuels the massive wealth inequality, rampant militarization, and perpetual debtor status (both within nation-states and across international borders). In applying neoliberalism as an investigative framework in both historical and contemporary Palestine, this work sees linkages among the forces arrayed to drive up profit margins, increase private wealth, and exploit the politically vulnerable while eradicating the region's long-term historical community enfranchisement and social safety measures. 
Moreover, this study considers neoliberalism and its deleterious effects on both historical and contemporary Palestine primarily as a non-local force driven by political and economic elites who are far removed from the subsequent political violence. ${ }^{4}$ It is not my intent to negate the centrality of indigenous, Palestinian nationalism present within the contemporary political conflict or to overlook the impact of imported, Jewish nationalism in stoking the fires of political conflict in post-war Palestine. These narratives are vital starting points in academic explorations of this conflict and remain fundamental for expressions of identity, selfhood, and community from within the affected areas.

Yet even while recognizing the absolute necessity of indigenous agency in discussions of Palestine-Israel, this work will analyze the political and economic policies enacted by parties who were - or are - often many miles away from the actual conflict zone. For some, an analytical emphasis upon these political actors within both historical and contemporary narratives may represent an attempt to divert one's attention from the nascent political contest and, as such, might be criticized for its theoretical role in removing agency from the region's primary actors. Nevertheless, the subsequent discussion, which investigates the policies and motivations of political and economic elites who were non-local ${ }^{5}$ to the evolving contest of oppositional national movements in historic Palestine, engages vital aspects of inquiry into the historical development of Middle Eastern conflict. Furthermore, the following analysis on the role of outside arbiters in promoting national conflict within the Middle East suggests elements of political and economic continuity that connect motivating factors for historical conflict with contemporary interests responsible for the conflict's ongoing perpetuation.

This investigation, therefore, seeks to establish and describe the international nature of historical, political, and economic forces that were present at the inception of the post-WW1 crisis in the Middle East and to connect them to the enduring and utterly injurious neoliberalization of contemporary Palestine-Israel.

\section{Finding the Origins of the Palestinian-Israeli Conflict}

A great deal of the prevailing historiography of this conflict postulates a contest of two oppositional national movements, each one coming to the foreground of international political considerations on the eve of the global crisis embodied by the First World War. A standard narrative describes how authors, intellectuals, journalists, and political advocates within European Jewry, ${ }^{6}$ mo- 
tivated by burgeoning nationalist movements throughout continental Europe during the nineteenth century, hypothesized the existence of a Jewish nation ${ }^{7}$ - a community united by a shared historical memory, cultural distinctiveness, religious practice and ritual observance, and common political aims, despite their dispersal throughout the nation-states of Europe.

This movement likewise derived its raison d'etre from a collective experience of centuries of religious, cultural, and economic persecution as a people, a process of brutality and negation that reached its pre-war feverpitch with orchestrated pogroms performed by citizenry and state officials against Jewish families, homesteads, and property in Tsarist Russia during the early $1880 \mathrm{~s} .{ }^{8}$ The shock of these pogroms and the prolonged trauma of isolation, negation, and institutional racism that pervaded European capitals during this period gave rise to the understanding among Jewish intellectuals that assimilation within European communities was neither possible nor desirable. In sum, two distinct but arguably equally powerful trends - a positivist element of tradition and community, and a negativist trend of virulent anti-Semitism - provided motivation for both the theoretical and practical formation of the Zionist movement, a nationalist ideology that would soon become one of the most influential and dynamic non-state actors within the capitals of Old Europe prior to and during the First World War. ${ }^{9}$

Unlike Jewish nationalism, a distinctly European political movement, the Palestinian national movement was cultivated from within existing communities in and around historic Palestine. ${ }^{10}$ And also unlike the documented inception and progression of the Zionist movement, the origin, nature, and historical development of the Palestinian national movement remains affected by a dearth of intellectual clarity as regards the distinct formation of a unitary, national, and political consciousness. According to Baruch Kimmerling and Joel Migdal, archival material from Ottoman-era Palestine - an administratively distinct and economically diverse ${ }^{11}$ series of towns, villages, and large urban areas dotting the coastal plain and interior hills of the eastern Mediterranean basin - indicates at least the nascent stages of a Palestinian national movement as early as the 1834 Arab Revolt. ${ }^{12}$

This watershed moment would indelibly orient Palestinians toward a modern, nationalist sensibility from the inception of the revolt to the eruption of national conflict after World War I. Rashid Khalidi, who concurs with this assessment, identifies a thriving national, political culture within Ottoman Palestine in the years prior to the substantial demographic shift 
wrought due to large-scale European Jewish immigration via aliyot, the Jewish spiritual "ascent" to the Holy Land from communities in Europe. ${ }^{13}$ Benny Morris would differ, claiming that the Palestinian insurrection against Ottoman authorities cannot be labeled "nationalist" except in an anachronistic attempt to attribute a unified, political sentiment to an otherwise disparate and divided population. By his account, political participation was motivated not by a modern and recognizable nationalist sentiment as such, but rather on behalf of more diffuse, collective causes that were predicated upon either religious or ethnic identification. ${ }^{14}$

Despite such disputes surrounding the nature and historical trajectory of Palestinian nationalism, the aforementioned scholarship substantially converges in its assessment of the historical conflict in Palestine-Israel as ultimately a contest of nationalisms. These national movements were either local and organically developed or non-local and imported, reacting simultaneously to both positivist and negativist influences within the existing cultural milieu before developing both the intellectual and the practical infrastructures for a viable and immediately influential national movement. Subsequent national political conflict in Palestine-Israel then revealed itself as the contentious expression of the incompatibility of these two national communities within a single, small province of the desiccated and collapsing Ottoman Empire. ${ }^{15}$

\section{Imperial Designs in Ottoman Palestine: The Neoliberal Architects of Political Crisis}

Outside of these two independently crafted and self-legitimated national movements, a third factor brought considerable influence to bear upon the region's political developments, thereby speeding up the collapse of the existing regional administration and deliberately creating a political void in the absence of Ottoman control. This factor would emanate from within seats of government in London, Paris, Moscow, and beyond - and long before the official outbreak of hostilities in the summer of 1914. Far from being impeded in their aspirations to lay claim to territories still within the control of another nation-state, Foreign Office administrators and retinues of imperial bureaucrats among the ostensible Entente allies in fact cultivated competitive rivalries over those Ottoman territories yet to be conquered. French, British, and Russian officials took great pains to communicate to one another their historical, cultural, or economic "rights" to sovereignty over large swaths of Ottoman territories in the years leading 
up to world war. ${ }^{16}$ In so doing, each of the Great Powers entering the First World War was bound by a series of military treaties and defensive obligations to one another while simultaneously being entrenched in both explicit and clandestine competition over territories, resources, and economic initiatives in the Middle East, Africa, and beyond. ${ }^{17}$

It is worth noting that for its part, British policy ${ }^{18}$ in the lead up to the First World War was primarily the preserve of a small war cabinet comprised of a handful of men who were career imperialists with long service records of working on behalf of the imperial government. More than having a vague admiration for the machinations of Empire, they were also collectively in favor of imperial control exercised via military power and were convinced of the necessity of imperial extension in order to maintain Britain's economic viability into the twentieth century.

[B]y 1917 Britain was ruled and its policies decided by a small war cabinet, formed by Lloyd George in December 1916. This concentrated all war strategy in the hands of, initially, five men: Lloyd George, Lord Curzon, A. Bonar Law, Arthur Henderson (representing the Labour Party), and Viscount Milner. Jan Smuts, Sir Edward Carson, and G. Barnes (replacing Henderson) joined during 1917 ... Never in modern times had the decisionmaking process in Britain been concentrated in so few hands. ${ }^{19}$

With the advantage of a small working group, British wartime policy could be formulated in London and disseminated to the seats of imperial power in Cairo, Simla, and elsewhere with comparative rapidity. More to the point, the policymakers themselves were a small number of men who possessed a broadly shared ideological perspective in which extending the British imperial project was considered not only good for the world and preferable to other forms of rival imperial operation, but also vital for the future of the British economy. In fact, this working group generated the policy that favored increased territorial acquisition and resource allocation. British claims to larger swaths of land and resources would continue throughout the war and into the ensuing Paris Peace talks.

One such imperial claim connected the British Empire with the hilly interior of the eastern Mediterranean basin, from the Jordan River to the sea and encompassing Jerusalem, the district's spiritual center. Comprising portions of two administrative districts within the Ottoman Empire (i.e., the vilayets of Aleppo and Damascus), ${ }^{20}$ Palestine was claimed within the context of pre-war imperial rivalries to be the exclusive purview of His Majesty's Government, and was clearly identified by British officials as a 
vital territorial concern, a territory that was absolutely necessary to the health, security, and, most importantly, the vitality of the British imperial economy from Suez to the Subcontinent.

Palestine had been a British concern ... ever since the occupation of Egypt in 1882. By 1900 the British had forced the [Ottoman] Sultan to withdraw his forces north from the Suez canal. They had surveyed the land as far north as Acre, blocked a French scheme for extending the French-owned railway to El-Arish, and in 1914 got German recognition that Palestine lay within a British sphere of interest. In 1915 the de Bunsen Committee accepted the view, put forward by Sykes, but probably representing Kitchener's views that both western and eastern Palestine, from the line west-east from Acre to Dar'a and south to Aqaba and the Egyptian frontier, lay within the British sphere of interests. ${ }^{21}$

The British claim to political sovereignty in and over Palestine soon came to embody one of the most crucial war aims emanating from the War Cabinet. Wresting it from Ottoman control would mean access to the Suez Canal, increased regional militarization, and the imposition of exclusive British control of commercial traffic from ports in the east through to the Mediterranean and on to Europe. Far beyond the accrual of imperial prestige that London would gain through this conquest, or as a defensive policy designed to keep imperial rivals out of the area, British interest in Palestine during this period can be seen to have been motivated primarily by economic reasons.

This claim was contested, however, by competing claims of French sovereignty over, and influence within or adjacent to, areas of the Mediterranean interior. Broadly asserting their claim to Ottoman Syria, official French correspondence from the period pushed back against the sweep of British authority in the Mediterranean region and posed counter-claims that asserted their own political, cultural, and economic dominance in the region. In order to negotiate these overlapping claims, representatives of both countries met to divide up then-sovereign Ottoman territory among themselves in closed-door discussions that have since come to represent the very height of imperial covetousness.

In a meeting in May 1916, Sir Mark Sykes of the British Foreign Office and his counterpart in the French Foreign Ministry, George Picot, divided the Arab Middle East between them into two spheres of influence and into new political entities ... This division broke promises made by the British Government to Sharif Husayn. In his letters, Husayn had stated 
that he wished for an extended reign, for himself and his four sons, and possibly for representatives of the embryo Arab national movement over all the Arab former provinces of the Ottoman Empire. The British agreed in principle, but cautioned Husayn that in certain areas, which they defined vaguely, they had to consider other interests, such as those of the French and the non-Arab minorities. These considerations became the major criteria in the Sykes-Picot Agreement. ${ }^{22}$

The Sykes-Picot Agreement detailed here embodied the pact between British and French representatives that ensured their shared claim to hotly contested territories to be annexed upon the defeat of the enemy Ottomans. Sir Mark Sykes (closely connected to the British War Cabinet) had been dispatched to deal with the French claims to the Syrian interior and to extract an agreement with the French that would be as favorable as possible to the British imperial motives. Other interested parties who claimed sovereignty over Ottoman territories, namely, the indigenous Arab population, were relegated to second-class status with their religious, political, and economic rights being likewise cast aside in favor of the newly joint British and French imperial operations in the Middle East. By relegating these rights, the Sykes-Picot Agreement undid earlier British commitments guaranteeing Arab independence and autonomy in the region to Husayn, Sharif of the Hejaz, and Keeper of the Holy Cities of Makkah and Medinah. ${ }^{23}$

Added to this already convoluted diplomatic picture was the November 1917 assurance granted by the British government in the form of a brief but now famous letter authored by the British foreign secretary, Arthur Balfour, to a prominent British Zionist and the first Jewish peer in British history, ${ }^{24}$ Lord Walter Rothschild. In part, this letter declared, in part: "His Majesty's Government views with favour the establishment in Palestine of a national home for the Jewish people." ${ }^{25}$ In allowing the passage of the Balfour Declaration, the British government emboldened the aspirations of yet another political actor, the Zionist movement, for enfranchisement and autonomy in historic Palestine.

In the course of their duplicitous dealings with various regional and non-regional actors during this period, the British government revealed the underlying motivations at the heart of wartime diplomacy in the Middle East. Britain desired extensive territorial possessions and regional control in the Middle East with concomitant levels of political autonomy, economic benefit, and market securitization. It further aimed to secure international acquiescence to the seizure of huge sweeps of resource-rich territory (i.e., 
modern-day Iraq, Palestine, and Jordan) and then sought to position itself as the primary beneficiary of these resources via a newly innovated pseudocolonial relationship known as the Mandate System. Through these largely successful efforts, the War Cabinet and its coterie of supporters significantly expanded British territorial control in the region, thereby also underwriting the British imperial mission in India, Egypt, and sub-Saharan Africa.

British strategy in the Middle East during World War I further married private, for-profit industry with state functions in prosecuting the war: manufacturers, industrialists, and capitalists worked hand in glove with imperial officials to survey, securitize, and map the new areas of European sovereignty in the post-war Middle East. The rights of the region's indigenous populations were decidedly secondary to this push for resource acquisition and economic expansion. Upon being exposed to the degree to which British promises involved unfaithful assurances made to various international actors, Chief of the Imperial General Staff Sir Henry Wilson remarked: "We have made so many promises to everybody in a contradictory sense that I cannot for the life of me see how we cannot get out of the present mess without breaking our word to somebody." 26

The contemporary Palestinian-Israeli conflict was born among these oppositional political and intellectual movements, each of which was guaranteed legitimacy and autonomy by a body (i.e., the British Empire) that was only interested in maximizing its own profit margins and political security via these diplomatic maneuvers. The resulting dispute among British imperial authority, Palestinian national interests, and the growing Zionist community in Palestine brought about an economic crisis followed by mass popular protest among the indigenous community, namely, the Arab Revolt of 1936-39. ${ }^{27}$ After decades of costly, counterproductive rule and crippled by the Second World War, the British government abrogated responsibility for this post-war colonial holding by relinquishing the future of Palestine and its peoples to the newly established United Nations. Unable to implement a just solution in service of two countervailing national movements, war erupted in 1948.

The resulting conflagration saw the newly settled European Zionists triumph over the indigenous population and the latter's ostensible Arab allies. During the war, between 700,000 and 750,000 Palestinians were ejected from their homeland. Opportunistic Arab commanders from neighboring states fled back across new regional borders, leaving historic Palestine's communities broken and disjointed. The Zionists proclaimed the 
establishment of the State of Israel at midnight on May 14, 1948. ${ }^{28}$ The State of Palestine has never come to fruition.

\section{Neoliberalism Defined}

The particular pattern of deception, conquest, security, and control embraced by the British during the First World War in the Middle East reflects a military, political, and economic strategy of resource acquisition and market securitization that displays a prototypical form of international neoliberalism. Securing resources for cultivation and markets for the distribution of goods had long been a central aspect of Europe's imperial project in Africa, Asia, and the Middle East. And although these practices were not named as such in period discourse,${ }^{29}$ the intertwining of privatized, commercial interests with state-led, public policies combined with the strong emphasis on the securitization of private markets enacted on the heels of global crises $^{30}$ (e.g., a fully engaged, multi-theater world war) stand as stark evidence of what would today be identified as distinct components within the neoliberal economic system. The embrace of the private market as a political priority ahead of public concern, political enfranchisement, or human rights inherent to the neoliberal project connects the practices of empire in the First World War to the practices of globalized, private capital today in the Middle East. It is to that connection, and the specific manner in which international capital influences Palestine-Israel from power centers outside of the conflict zone itself, that this study now turns.

The connection between the conduct of empires in their various historical contexts and the contemporary manifestation of the neoliberal order is plain: "The neoliberal regime and the imperial turn have in common that they are doctrinaire and involve vast military spending and spin and marketing." ${ }^{31}$ Each institution is characterized by monumental political, military, and economic power; each manifests itself globally, operating without a single, dedicated infrastructure in any one particular location; and each incorporates the functional political and economic components of national and international institutions in order to enact the policies of securitization, privatization, and negation that are their calling cards. Both empire and neoliberalism constitute comprehensive power structures that can be characterized by their unyielding commitments to the mastery of both regional and international economies in order to benefit a small group of political and economic elites. Quite typically, the same individuals retain membership in 
both privileged groups. Indeed, in some formulations these two concepts are in fact two names for the same set of processes carried out at different historical points: "neoliberalism is inseparable from imperialism and globalization" given that "in the conventional (or mainstream) discourse imperialism is [simply] absent." 32

Contemporary neoliberalism enacted on a global scale is further characterized by the push toward complete economic deregulation, expansive corporate profit margins, and the aggressive and irrevocable reduction of the state as a provider of services of all kinds, including and especially health care, education, environmental protection, and food and drug regulation. According to geographer David Harvey:

Neoliberalism is in the first instance a theory of political economic practices that proposes that human well-being can best be advanced by liberating individual entrepreneurial freedoms and skills within an institutional framework characterized by strong private property rights, free markets, and free trade. The role of the state is to create and preserve an institutional framework appropriate to such practices. The state has to guarantee, for example, the quality and integrity of money. It must also set up those military, defence, police, and legal structures and functions required to secure private property rights and to guarantee, by force if need be, the proper functioning of markets. Furthermore, if markets do not exist (in areas such as land, water, education, health care, social security, or environmental pollution) then they must be created, by state action if necessary. But beyond these tasks the state should not venture. ${ }^{33}$

Harvey describes an all-encompassing philosophical approach to global economic and political order through which all forms of human endeavor are attended by a price tag. In more concise terms, he confirms that neoliberalism can be understood conventionally as the "commodification of everything," ${ }^{34}$ a worldview in which war, occupation, and the machinations of political and social conflict also have an applicable and adjustable market value.

Further definitions of neoliberalism establish that the very nature of society, human rights, freedom, and individuality are redefined within the neoliberal system. This system's architects use powerful methods of sloganeering and ubiquitous forms of social and commercial media to enforce the tenets of rampant privatization and to assert that alternative philosophies to market operations are antithetical to liberty, justice, and the idealized human condition. 
Attempts to limit competition are treated as inimical to liberty. Tax and regulation should be minimised, public services should be privatised. The organisation of labour and collective bargaining by trade unions are portrayed as market distortions that impede the formation of a natural hierarchy of winners and losers. Inequality is recast as virtuous: a reward for utility and a generator of wealth, which trickles down to enrich everyone. Efforts to create a more equal society are both counterproductive and morally corrosive. The market ensures that everyone gets what they deserve. ${ }^{35}$

The idea of freedom is recast within neoliberalism to mean the freedom to privatize, the freedom to monopolize, and the freedom from contributing anything to any state or community-led social or public programs. Any and all collectives are anathema to neoliberalism. Even basic human services like water and heating ought to be given over to private companies so that their distribution can be regulated by the free market and priced accordingly. All goods and services necessary for human existence are to be attended with a price tag. Those who cannot afford the price that the market sets are castigated for their poverty while those who benefit from this architecture are considered meritorious. This system is lauded as just and righteous.

\section{Neoliberalism and War}

But there is one state function that embraces the tenets of neoliberalism to an even greater extent than those listed above: war. In fact, according to some scholars of this new globalized market philosophy, war is an ideal policy option for fulfilling both the ideological thrust and the economic objectives of neoliberalism in the creation of new, flourishing markets for war materials and support industries. ${ }^{36} \mathrm{~A}$ war fixed by achievable military objectives can yield massive profits to private industries, whose remit it is to provide goods and services to the machinery and the personnel associated with military deployment. More profitable still, however, is a war that has no fixed objectives or a rigid timeline for its execution. Under these conditions, the supply of goods and services associated with military deployment can be extended indefinitely. A clear example of this is Washington's ongoing "war on terror," defined and described by the George W. Bush Administration in 2001 and still officially ongoing. In David Keen's analysis, this limitless global war represents the ideal neoliberal policy. Indeed, it was intended to be an Endless War, as his 2006 work is named, even if this policy goal is scarcely (if ever) articulated publicly. ${ }^{37}$ 
Regardless of public protestations from neoliberal policy architects, it is evident that a robust pro-war policy suits neoliberalism's articulated and implied objectives. In the first place, being at war lays the groundwork for future market expansion in the form of reconstruction and rehabilitation of denuded areas and debilitated societies. Neoliberalism holds that the destruction of a civilization is far from the end of wartime objectives, but rather the reconstruction of that which has been destroyed by the military machine is intended and planned within the act of destruction itself. $\mathrm{Nu}-$ merous contemporary examples bear this out, but none more so than the US prosecution of war in Iraq from 2003, which has seen billions of federal dollars poured into the reconstruction of the roads, bridges, and civil infrastructure eliminated by the US military itself during the war.

The deals aimed at rebuilding Iraq's oil, water and electricity infrastructure were given to American firms - such as Parsons, Fluor, Bechtel and Halliburton - not to Iraqi businessmen with firsthand experience rebuilding the country after the 1991 Gulf war. For US contractors, "reconstruction" has been a bonanza. In April 2004, the most notorious of the Iraq war profiteers, the oil services corporation Halliburton, announced that its Iraq contracts made up $\$ 2.1$ billion of the company's first-quarter revenues of $\$ 5.5$ billion. These contracts helped to offset the company's losses in its other operations. ${ }^{38}$

The state-funded process of diverting billions of public funds into the coffers of private enterprise is a typical example of "international neoliberalism," a form of privatization and market control enacted upon a recipient district, region, or state. That is, instead of allowing indigenous reconstruction of sovereign Iraq, US planners funded their own reconstruction projects. In so doing, they diverted virtually all of the funds injected into this process away from Iraqi firms. Reconstruction after the fact then becomes a highly profitable arm of the neoliberal enterprise. Effectively, this aspect of idealized war means that "capitalist imperatives have become the defining feature of our contemporary global militarism," "39 a facet of modern warfare that actually has its roots in global conflicts from a century ago. ${ }^{40}$ Since then, war has become more frequent (even ceaseless), more destructive (especially to civilian populations), more industrialized, and ever more profitable for private industry.

This final aspect of modern warfare - profitability - is an irreplaceable tenet of the neoliberal system. According to this feature, the productive functions of the state with regard to military hardware, equipment, supply, 
and support are eroded in favor of profit-driven private actors. In keeping with neoliberal tradition, the military is only one aspect of the state's function insomuch as it is used to serve the articulated policy goals of state governments. For while it is the state that recruits its citizens, trains them, and determines when war is the chosen policy, it is, in fact, private industry that feeds, clothes, transports, houses, and entertains soldiers once they are deployed. Indeed, the story of war for profit throughout the twentieth and twenty-first centuries is best understood through the lens of market creation for private industry. Today, commoditization is rife in theatres of war and private industry; neither the citizenry, nor the soldiery or the state (conceived of as a guardian of the public good) is the beneficiary of that process. Rather the architects of the neoliberal system - the neoliberal elites - benefit mightily in both material and political terms. ${ }^{41}$

The production of weapons and the attendant military hardware likewise conforms to this model. The age of state-run arms manufacturers has given way to a thriving, profit-driven arms industry wherein wares are produced, marketed, and sold to interested bidders..$^{42}$ Government agencies (from the US, Europe, Asia, and elsewhere) rank among the most generous of competitive bidders, given that they have access to state funds in order to purchase the newest equipment and technology from weapons and systems manufacturers. ${ }^{43}$ And like other market commodities, armaments are manufactured and sold in order to be used; unused equipment identified by government contractors becomes largesse, a wasteful glut of supply that could prove burdensome to the purchaser. The idea of military supply being connected to normal functions of commodity markets and freely traded capitalist products has begun to beg questions relating to both overt and clandestine connections between foreign policy and its architects, and between market considerations associated with the profitability of armaments.

$[P]$ rivate ownership and the market-driven character of the arms industry have drastically changed the conventional relationship between the supply of and demand for arms ... modern wars and the demand for armaments and munitions are nowadays precipitated more by sales and/or profit imperatives than the other way around. ${ }^{44}$

As manufacture and support for the systems and weapons of war are removed from state-owned hands and placed under the purview of private profiteers seeking expansive markets for their increasingly profitable products, state planners begin to make decisions based as much upon market 
concerns for their product as upon an assessment of immediate threat or long-term national interest. And, as indicated previously, these processes are further compromised by the fact that "the 'principal architects' of the neoliberal 'Washington consensus' are the masters of the private economy [including] huge corporations that control much of the international economy and have the means the dominate policy formation." ${ }^{45}$ In short, policy decisions about relentlessly destructive warfare around the globe are frequently made by the same individuals who stand to profit mightily from the use of war as policy in a given international conflict zone. ${ }^{46}$

Neoliberalism teaches, then, that where there is war there is a market, and where there is a market profit can be made. Public interest, civilian safety, and preserving global peace are all subservient to these considerations. Tellingly, this new global reality has been acknowledged by some of its former architects, applied recently and with devastating effect by US military forces in the Middle East. The chief of staff to the George W. Bush Administration Secretary of State Colin Powell, Colonel Lawrence Wilkerson, acknowledged in a recent interview that "it is now private interests that benefit most from our use of military force." $" 47$ It is this conflation of public and private that stands at the heart of the neoliberal ideal and that continues to prove troubling for those who would seek transparency in foreign policy actions. Without such transparency, the interests being served in twenty-first-century police actions should now be assumed to be, in Wilkerson's terms, "private interests" fully in keeping with the parameters of neoliberal theory. War in defense of the state, then, whether pre-emptive or as a reaction to foreign aggression, can no longer be said to be in the public interest. Indeed, through these practices, "We've privatized the ultimate public function: war." 48

\section{Palestine-Israel and the Neoliberal Ideal}

Neoliberalism is an avaricious global force that works to connect aspects of international warfare, domestic politics (primarily in the Global North ${ }^{49}$ ), political geography, and unfettered market capitalism. As an outgrowth of the development of modern capitalist societies, the neoliberal ideal has been applied and extended in a variety of international locales in order to create and re-create markets. When market creation is achieved via warfare, the conferred legitimacy of the state is used to validate what is, in effect, a private for-profit venture.$^{50}$ In the American context, as often as not, these ventures are characterized by highly mediatized flourishes: sudden bursts 
of violence applying an overwhelming amount of military force followed by long periods of lull in which market reconstruction comes to fruition by way of societal rehabilitation and structural redevelopment: the winning of "hearts and minds" that follows the "shock and awe."

These phrases are exemplary demonstrations of how "neoliberalism has ... become hegemonic as a mode of discourse. It has pervasive effects on ways of thought to the point where is has become incorporated into the common sense way many of us interpret, live in, and understand the world." 51 Given the unparalleled nature of the contemporary military strength of the US, this model has had a number of successful applications throughout both political and discursive spaces of the developing world. As mentioned, nowhere has this neoliberal playbook been more steadfastly adhered to than in the destruction and ongoing reconstruction of Iraq over the course of the last decade, where the American establishment has "sought to impose by ... force on Iraq ... a state apparatus whose fundamental mission was to facilitate conditions for profitable capital accumulation. ${ }^{\circ 2}$

But the aforementioned model for the military and industrialized application of the neoliberal ideal is not the only method through which market expansion is achieved within this framework. Like the invasion and forcible conversion of previously autonomous spaces into profit-driven market creations, slower, more deliberate patterns of warfare and political violence also suit the application of forcible privatization. One such case is Palestine-Israel, where ethno-nationalist tensions coupled with the political manipulations of self-interested outside actors ${ }^{53}$ have engendered a long-running social, political, and military conflict. In its contemporary form, the specter of international neoliberalism looms large as elements of corporate investment, privatization, and rampant surveillance and militarization have become a means unto themselves within the erstwhile contest for autonomy, dignity, and political enfranchisement waged by the Palestinians against fifty years of Israeli occupation.

The assertions made below will focus upon how the aforementioned principles of contemporary international neoliberalism apply to this conflict, while my concluding remarks will seek to tie together the various threads at work in this study: neoliberalism as imperialism in the conflict's origins; the precepts of contemporary international neoliberalism; and the global neoliberal characteristics of contemporary Palestine-Israel.

Taking Palestine as a case-study of operational neoliberalism in the twenty-first century, it is possible to see the multiple and multi-faceted economic benefits presently being derived by non-local agents from the 
perpetuation of conflict between the region's warring national groups. These material benefits result from political designs that allow transnational actors to generate profits by even within an outwardly liminal and stilted political conflict. That is to say, the complex machinations of international policy endemic to Palestine-Israel have not stopped the neoliberal elites from securing markets and extracting profit from commercial operations in the region. On the contrary, the present political structure of Palestine-Israel, one in which the civil control and military occupation of a people is daily enacted and constantly reinforced, constitutes a political and economic reality that is well-suited to the structures of the international neoliberal economic model.

The economic and political elites that structure international neoliberal policy stand to benefit from the continuation of Israel's occupation of Palestine primarily through four distinct although complementary methods. As before, the following examples will focus on those international neoliberal practices that connect the flow of capital from the Global North with the most readily available market spaces. The process of privatization and neoliberal practice within Palestinian society engaged by indigenous neoliberal elites are therefore not considered.

1. Corporate Expansion. US-based and international corporations take advantage of the contested status of the Palestinian West Bank. Also called "Judea and Samaria" by those committed to the Israeli state narrative in the discursive aspect of this conflict, the West Bank is the internationally recognized home of the future Palestinian state. In practice, however, today it is today a disambiguated and heavily militarized geographical and political space in which indigenous Palestinian communities are kept largely separate from one another via a series of Israeli-only bypass roads connecting its Jewish-only enclaves. ${ }^{54}$ This ethnic separation and physical exclusion is enforced by the Israeli military, which maintains checkpoints and patrols Palestinian towns and villages in order to implement Israeli policies of ethnic exclusion.

A number of international companies including Motorola, SodaStream, Ahava (and Ahava, USA), Intel, and CAT (Caterpillar Inc.) operate within the Occupied Territories, exploiting local markets while benefitting from the low operational costs afforded to them by the Israeli government in order to incentivize regional development within controlled market operations. Indeed in some cases, as with Caterpillar, Inc., which innovated a militarized model of their largest bulldozer named the D-9 complete with 
mounted machine-gun, which has been used to enforce collective punishment against Palestinian individuals and families resisting the occupation, certain US corporations have begun to take an active role in enforcing Israeli occupation policies. Through these practices, companies embrace the quintessential neoliberal ethos by commodifying conflict, effectively taking advantage of the unique conditions present in Palestine-Israel for corporate expansion and profit maximization. These companies are among those that directly profit from the conditions of occupation and negation, indicating the neoliberal preference for profit over peace. ${ }^{55}$

2. Civil Policing. The assault on the state's social foundations embodied in neoliberalism does not necessarily result in weak states, just weak societies whose populations become subject to the market's amoral vagaries in order to obtain even their most basic of human needs. As for the state itself, it retains its Weberian remit to wield all legitimate force and redirects its political and administrative energies toward the sustenance and, indeed, the determined expansion of that remit. Hence, states embracing the tenets of neoliberalism can typically be identified by the location of two complementary yet directionally differentiated institutions of force and control: a large military and an expansive civil police force.

With regard to policing, growing numbers of US municipalities as well as federal law enforcement agencies have engaged in policing and training exercises with members of the Israeli police force and military units in order to improve upon the existing methods of surveillance, restriction, and control that become necessary within neoliberal states that embrace and encourage massive redistribution of wealth to a minority political and economic elite. Police forces in Atlanta, St. Louis County (home to Ferguson), and Knoxville are among those police agencies that have collaborated, cooperated, and trained with Israeli military forces in recent years. ${ }^{56}$

Widespread US-Israeli cooperation among police and military units promotes an expansion of violent, hyper-militarized methods of policing in the United States while substantially underwriting US support for notoriously violent Israeli policing, crowd-control, administrative detention, and other police and military operations. Through this relationship of control, the Israeli occupation of Palestine is ideologically as well as economically beneficial to the United States because it provides ever-present grounds for robust tactical operations of state violence against subject civilian populations. ${ }^{57}$ 
3. Technologies of Surveillance and Control. Surveillance and intelligence technologies have flourished inside Israel since its occupation of Palestine, ranging from perfecting and mass-production of cellular communication technology to the expansive deployment of offensive drone technologies. In keeping with its own nascent neoliberal tradition, the Israeli state has successfully married private industry, aggressive militarystate policy, and higher education in order to immediately apply innovations within research and development at various academic institutions within the country (particularly the Technion in Haifa). These are then used to meet the state's goals, especially the continued erosion, through military means, of the cultural and geographical integrity of the Palestinian cultural areas under Israeli control. ${ }^{58}$

The most relevant application of neoliberal theory comes, however, in the aftermath of Israel's innovation, mastery, or mass production of technology with potential military applications. As is often the case, neoliberal states actors, especially the US, will take advantage of military and civil technology exchanges and purchases with Israel, retool the product in question, and expand the military applications of a given technology in order to allow the US to eventually surpass its client state in the widespread use and broad application of technologies of surveillance and control (the use of drone strikes to eliminate political targets throughout the Middle East and South Asia is a particularly salient example within this operational mode ${ }^{59}$ ). In this manner, technological innovation, especially technology with the potential to extend state control of civilian populations and/or eliminate political enemies of the state, benefits substantially from Israel's position as an occupying power with an indefinite mandate for its military operations in the region.

4. Defense Contracts. Arguably the largest and most beneficial (in neoliberal terms) result of the ongoing Palestinian-Israeli conflict is the unprecedented military build-up among neoliberal states (with particular emphasis on the US) and subsequent contractual exchanges with Israel that allow for neoliberal defense industries to expand to unprecedented limits after having been underwritten by state financing.

In conventional terms, unchecked state support of war industries proceeds according to contractual obligations with allied states, especially those that may appear to be imperiled by oppositional regional or international forces. As has been well-documented, US military provisions to Israel are unparalleled in diplomatic history. ${ }^{60}$ Fulfilling these contractual 
obligations annually requires the United States to construct and maintain history's largest military, a policy that likewise requires Israel to maintain a need for military-grade weaponry and material. Both states are served in this regard by forestalling peace and by prolonging war and occupation.

Neoliberal state practice in the United States is further sustained through weapons exchange with Israel by allowing the US government to sustain Northrup-Grumman, Lockheed-Martin, Bechtel, Raytheon, and other defense contractors through weapons sales to Israel, using foreign policy in an ongoing political conflict to underwrite the already unprecedentedly robust US military. In domestic policy these arrangements are not labeled as federal subsidies; however, in practice military contracts and agreements for weapons sales such as the ones the US maintains with Israel on an annual basis work to provide precisely the kind of support to the US defense industry implied by the term subsidy.

The ongoing conflict in Palestine-Israel, the prolific and very public failure of the internationally endorsed peace process over the course of the last decade and more, and the perpetuation of episodes of war and other forms of low-level state violence fit hand-in-glove with the tenets of neoliberal principles. It is accurate, therefore, to say that the US and other global neoliberal giants treat Israel substantially as a regional Sparta, using its strategic position as an occupying power over and above a subject populace in order to advance and solidify the neoliberal state control of their own civilian population as well as to support the unprecedented expansion of state militaries and their attendant civil and corporate partners.

\section{Conclusions: Neoliberalizing the Palestine-Israeli Conflict}

When approaching a dynamic concept such as neoliberalism and its symbiotic relationship with both domestic and international affairs, it is crucial to remember that their architects never meant for such concepts to exist in a theoretical space. ${ }^{61}$ Rather, institutions of state power and control must be actively and regularly applied to provide the political justification for their growth and development, as well as to provide persuasive rhetorical momentum for their imperative need among ostensibly democratic constituencies. These constituencies are consistently and continually fed narratives according to which both internal and external threats exist simultaneously (e.g., immigration and terrorism, class warfare and disease, gun control and 
nuclear proliferation), thereby propelling popular demands for a robust military apparatus as well as a heavily armed and highly visible civil police force. $^{62}$

In addition, the US and its neoliberal allies incorporate elements of Palestinian resistance to Israeli occupation, as well as to regional state and non-state opposition to Israeli occupation policies, into those discursive narratives that sustain state policy within the authoritative news media. This is evident in the print and televised news strategies to identify all form of Palestinian resistance to Israel - especially armed resistance - as terrorism enveloped within a deterministically constructed global international conceptual conflagration known as the "war on terror." The great lengths sustained by the neoliberal states' authoritative media in order to connect divergent and distinct groups of actors under the blanket of one broad antithetical coalition require that necessary strategies be set into motion in order to preserve the expansive pro-military and pro-corporate policies endemic within the neoliberalism system.

As with the imperial projects of the early twentieth century, contemporary processes of neoliberalism manifest themselves as another set of non-local political and economic forces driving the machinations of conflict in Palestine. These dynamic but entirely complementary factors maintain the substance and provide for the enduring forward momentum of political conflict in that region, thereby substantially remaking the conflict not as a contest among oppositional national groups with historic and justifiable claims to a nation-state or to a homeland in the land in question. Rather, the functional political and economic confluence in question exists to actively subsume Palestine-Israel in the contemporary era, objectifying the totality of its physical and political space and reconstructing regional political geography into an established dystopia of ceaseless war and unending political violence. The form of this violence is less often that of aerial bombardment, military assault, or naval barrage, but is rather more often manifested in the historically unprecedented depth and complexity of the ongoing military and civil occupation of a distinct and articulated indigenous, national group by another political entity.

\section{Endnotes}

1. Instrumental in theorizing the relevance of both positive and negative associations for the development of a modern collective and observable national consciousness in Palestine is Rashid Khalidi's seminal Palestinian Identity: 
The Construction of a Modern National Consciousness (New York: Columbia University Press, 1997). This postulate was later extended by James Gelvin in his The Israel-Palestine Conflict: One Hundred Years of War (Cambridge: Cambridge University Press, 2005).

2. On the concept of "de-development," see Sara Roy, "De-development Revisited: Palestinian Economy and Society Since Oslo," Journal of Palestine Studies 28, no. 3 (spring 1999): 64-82.

3. Although this article attempts a long durée approach to the history and contemporary expression of political conflict in Palestine-Israel, it is not necessarily bound by a particular theoretical or methodological approach. Rather, the work herein envisioned represents primarily a connective sketch of transnational forces that have been working in the Middle East for the last 100 years. As such, I will draw on multiple disciplinary and theoretical approaches.

4. It is important to distinguish between two complementary though differentiated types: "internal neoliberalism" (i.e., the policies of privatization, securitization, and restriction that occur within states) and "international neoliberalism" (i.e., the same practices, although exercised by the architects of neoliberal policies outside the areas of sovereign control). For the purposes of this study, I will be focusing on how external forces exert their influence upon Palestine-Israel in both historical and contemporary contexts, taking examples as evidence from international or global neoliberalism as well as from the long record of European imperialism in the broader Middle East. A number of studies, however, consider the internal neoliberalization of Palestine through policy measures enacted by, or with the acquiescence of, Palestinian political and economic elites from within the Palestinian Authority's ruling caste. For more information on this topic, see Adam Hanieh's "Palestine in the Middle East: Opposing Neoliberalism and U.S. Power, Part 1 and Part 2," Monthly Review: An Independent Socialist Magazine 19 (19 July 2008) and Raja Khalidi and Sobhi Samour's "Neoliberalism as Liberation: The Statehood Program and the Remaking of the Palestinian National Movement," Journal of Palestine (winter 2011), among other crucial pieces of scholarship that explain the processes of neoliberalization being enacted within occupied Palestine.

5. It is important to differentiate between two distinct uses of the term non-local in this study. In the first instance, the Zionist movement developed as a nonlocal national movement, constructing the intellectual and political parameters for Jewish nationalism from within Europe and ultimately directing that nationalist infrastructure toward settlement, land acquisition, and eventually the establishment of a state within historic Palestine. As such, within this specific context this term refers only to its inception, not to its propagation and ultimate fruition in the Middle East decades after its invention in Europe. A more prevalent use of non-local in this work refers to both the imperial and neoliberal 
actors both in Old Europe and in the contemporary West. Unlike the Zionist movement, these actors intend (and intended) to manipulate the political conflicts in the Middle East from afar, secure as they are/were in their respective political infrastructures that are far from the zone of conflict.

6. Foundations of Jewish nationalism within Europe arguably began with Eugen Duhring's 1881 publication of The Jewish Question, which considered the Jews' plight within Europe from a nationalist perspective. This was followed up the next year by Leon Pinsker's Auto-Emancipation: A Warning to His Fellow People, from a Russian Jew, which advocated the development of a national consciousness among Europe's Jews. Each of these works, along with movements in support of ethno-nationalism throughout nineteenthcentury Europe, contributed to the arguments of Theodore Herzl (considered the father of Zionism) in his 1886 publication Der Judenstaat, which considered the "Jewish Problem" a national one that should be resolved by granting the Jews sovereignty over a corner of land in Europe. See David Lesch, The Arab-Israeli Conflict: A History (New York: Oxford University Press, 2008), 28-29.

7. A thorough analysis of the history of the intellectual development of the concept of Jewish nationalism can be found in Shlomo Sand, The Invention of the Jewish People (London: Verso, 2009).

8. Lesch, The Arab-Israeli Conflict, 27-33.

9. Gelvin, The Israel-Palestine Conflict, 46-55.

10. Lesch suggests that both Zionism and Palestinian nationalism were children of nineteenth-century Europe's nationalist movements. Other scholars posit that the Palestinian experience in the 1834 Arab Revolt gave their national movement a differentiated trajectory (i.e., local and organic) that opposed Ottoman and Egyptian authority in Palestine's interior. The argument here is not that Zionism or Palestinian nationalism are more or less legitimate than one another, but rather that the Palestinian national movement was a local phenomenon, whereas Zionism developed non-locally and then selected Palestine as a destination for the culmination of its national and political aspirations.

11. For a detailed accounting of the economic activity in Ottoman Palestine, see Jacob Norris, A Land of Progress: Palestine in the Age of Colonial Development (Oxford: Oxford University Press, 2013).

12. Baruch Kimmerling and Joel Migdal, The Palestinian People: A History (Cambridge, MA: Harvard University Press, 2003).

13. Khalidi, Palestinian Identity.

14. Benny Morris, Righteous Victims: A History of the Zionist-Arab Conflict, 1881-2001 (New York: Vintage, 2001).

15 As underlined explicitly by, among others, Deborah J. Gerner, One Land, Two Peoples: The Conflict over Palestine (New York: Westview Press, 1994) and Ilan Pappe, A History of Modern Palestine: One Land, Two Peoples (Cambridge: Cambridge University Press, 2006). 
16. David Fromkin, A Peace to End All Peace: The Fall of the Ottoman Empire and the Creation of the Modern Middle East (New York: Holt, 2009).

17. Elie Kedourie, England in the Middle East: The Destruction of the Ottoman Empire: 1914-1921 (London: Bowes \& Bowes, 1956).

18. While all of the European states engaged in colonial projects during this period shared a number of practices, perspectives, and motivations, the British drive to colonize large swaths of territory in the Middle East is most relevant to the discussion here, for the League of Nations gave London trusteeship over Palestine (in the form of the British Mandate of Palestine) at the 1922 San Remo Conference.

19. D. K. Fieldhouse, Western Imperialism in the Middle East, 1914-1958 (Oxford: Oxford University Press, 2006), 132.

20. Pappe, A History of Modern Palestine, 15-18.

21. Fieldhouse, Western Imperialism in the Middle East, 138.

22. Pappe, A History of Modern Palestine, 66.

23. Due to the vague language and officious techniques of the British diplomatic corps in the Middle East at the time, even today there remain often vitriolic disputes about what exactly these officials promised to Husayn and the Arab nationalists with whom they communicated. For a discussion of this matter, within the context of the correspondence between Husayn and the High Commissioner of Egypt Sir Henry McMahon, see Elie Kedourie's In the Anglo-Arab Labyrinth: The McMahon-Husayn Correspondence and Its Interpretations, 1914-1939 (London: Routledge, 1976).

24. "Memories of the First Jewish Peer in History: Nathaniel Rothschild," The Jewish News Online (August 3, 2015), www.jewishnews.co.uk/memoriesof-the-first-jewish-peer-nathaniel-rothschild.

25. Gelvin, The Israel-Palestine Conflict, 88.

26. Kristian Coates Ulrichsen, The First World War in the Middle East (London: C. Hurst \& Co. Publishers, 2014), 156.

27. Gelvin, The Israel-Palestine Conflict, 107.

28. Ibid., 128.

29. Commentator George Monbiot has written about the inception of the term neoliberalism, explaining why its use as a reference to early twentieth-century imperialism is historically problematic: "The term neoliberalism was coined at a meeting in Paris in 1938. Among the delegates were two men who came to define the ideology, Ludwig von Mises and Friedrich Hayek. Both exiles from Austria, they saw social democracy, exemplified by Franklin Roosevelt's New Deal and the gradual development of Britain's welfare state, as manifestations of a collectivism that occupied the same spectrum as nazism and communism" ("Neo-liberalism: The Ideology at the Root of All of our Problems," The Guardian, April 15, 2016, https://www.theguardian.com/ books/2016/apr/15/neoliberalism-ideology-problem-george-monbiot). Still, I contend that the characteristics of imperialism during and after World War 
I may be legitimately compared with aspects of contemporary neoliberalism, even though the term itself was not in circulation until the latter stages of imperialism.

30. The use of local, regional, or global crisis in order to suspend or eliminate routine functions of law, economic regulation, or even human rights has been welldocumented as a typical strategy employed in order for economic elites to embed neoliberal principles within otherwise healthy or normally functioning social and economic systems in both historical and contemporary settings. In her The Shock Doctrine: The Rise of Disaster Capitalism (London: Penguin Books, 2007), Naomi Klein points to numerous such instances ranging from natural disasters to attempted coups to military threats from external actors. Indeed, Klein's work is relevant not only for its examination of the profound negative impacts of neoliberal policies in economic systems throughout the world, but also as a cautionary manual identifying the telltale signs of state-sponsored neoliberal programming on the back of systemic shock.

31. Jan Nederveen Pieterse, "Neoliberal Empire," Theory, Culture, and Society 21, no. 3 (2004): 119-40.

32. Alfredo Saad-Filho and Deborah Johnston, Neoliberalism: A Critical Reader (Ann Arbor, MI: Pluto Press), 2.

33. David Harvey, A Brief History of Neoliberalism (New York: Oxford University Press, 2005), 2.

34. Ibid.

35. Monbiot, "Neoliberalism."

36. James Tyner, Military Legacies: A World Made by War (Abingdon, Oxfordshire: Routledge, 2010); Chris Hedges, War is a Force that Gives Us Meaning (New York: Public Affairs, 2002); Noam Chomsky, Profit over People: Neoliberalism and Global Order (New York: Seven Stories Press, 1999).

37. David Keen, Endless War? The Hidden Functions of the War on Terror (London: Pluto Press, 2006).

38. Khalid Mustafa Medani, "State Building in Reverse: The Neo-Liberal 'Reconstruction' of Iraq," Middle East Report 232 (2004), www.merip.org/ $\mathrm{mer} / \mathrm{mer} 232 /$ state-rebuilding-reverse, 28-35.

39. Tyner, Military Legacies, 166.

40. See the above discussion on the linkages between contemporary neoliberalism and the age of imperialism in the nineteenth and early-twentieth centuries.

41. See William Greider's Fortress America: The American Military and the Consequences of Peace (New York: Public Affairs, 1998) for further explanation of these phenomena, especially as they apply to a pre-9/11, pre-"war on terror" world.

42. Andrew Feinstein, The Shadow World: Inside the Global Arms Trade (New York: Farrar, Straus, and Giroux, 2011), xxii.

43 Hollywood has dramatized this industry's unscrupulous nature on a number of occasions, recently in the 2016 film War Dogs, starring Miles Teller and 
Jonah Hill. Teller plays David Packouz, a real-life arms dealer who worked with Hill's character Efraim Diveroli to establish and operate a highly profitable arms trafficking company during the US invasion of Iraq. Diveroli and Packouz mimic the market behavior of official government contractors by targeting smaller arms packages that have been passed over by the larger and better-known contractors engaged in supplying the US military during its occupation of Iraq. The profitability inherent in war and occupation is taken as given in the film, with Packouz narrating at one point: "War is an economy. Anyone who tells you otherwise is either in on it ... or stupid."

44. Feinstein, The Shadow World, 16.

45. Noam Chomsky, Profit over People, 20.

46. William Keller, Arm in Arm: The Political Economy of the Global Arms Trade (New York: Basic Books, 1995).

47. Ben Norton, "“We are the death merchant of the world": Ex-Bush Official Lawrence Wilkerson Condemns Military-Industrial Complex," Salon, March 29, 2016,www.salon.com/2016/03/29/we_are_the_death_merchant_of_the_world ex_bush_official_lawrence_wilkerson_condemns_military_industrial_complex.

48. Ibid.

49. Here I borrow the term Global North, which has by now become ubiquitous in discussions of the inequality in global development and infrastructure. In discussions of the Middle East and the ongoing economic de-development of Palestine, see Jeff Halper's use of the term, especially in his recent work War against the People: Israel, the Palestinians, and Global Pacification (London: Pluto Press, 2015).

50. Pete Dolack, "Military Spending is the Capitalist World's Fuel." Counterpunch, April 22, 2016, www.counterpunch.org/2016/04/22/military-spendingis-the-capitalist-worlds-fuel.

51. David Harvey, A Brief History of Neoliberalism, 5.

52. Ibid., 7.

53. See the section above: Imperial Designs in Ottoman Palestine.

54. Neve Gordon, Israel's Occupation (London: University of California Press, 2008); Idith Zertal and Akiva Eldar, Lords of the Land: The War over Israel's Settlements in the Occupied Territories, 1967-2007 (New York: Nation Books, 2005).

55. Caterpillar, Inc. boasts sales of more than $\$ 11.3$ billion in the second financial quarter of 2017 alone (see their public, quarterly financial disclosures at www. aterpillar.com/content/dam/caterpillarDotCom/releases/2Q17\%20Caterpillar \%20Inc.\%20Results.pdf).

56. Sari Horowitz, "Israeli Experts Teach Police on Terrorism," The Washington Post, June 12, 2007; Mark LeVine, "Ferguson is Not Gaza ... Yet," Al-Jazeera America, August 18, 2014; Hira Mahmoud and Wafa Azari, "Police Training Exchange Compounds US, Israeli Racism," The San Francisco Bay View, May 6, 2011. 
57. David Kattenburg, "Global Palestine: An Interview with Jeff Halper," Mondoweiss, June 14, 2016, http://mondoweiss.net/2016/06/palestine-interviewhalper.

58. For a detailed explanation of Israel's role as a provider of niche technologies affiliated with military, surveillance, security, and control, see Halper, War against the People.

59. Simon Ostrovsky (producer), Israel's Killer Robots [Motion picture] (Vice Media, Inc., 2013).

60. John J. Mearsheimer and Stephen M. Walt, The Israel Lobby and U.S. Foreign Policy (New York: Farrar, Straus, and Giroux, 2007).

61. Chomsky, Profit over People, 1999.

62. A. Saad-Filho and Deborah Johnston, Neoliberalism: A Critical Reader (Ann Arbor, MI: Pluto Press, 2005); Klein, The Shock Doctrine. 